\title{
POLITICIZATION OF GLOBAL WARMING AND ENERGY RESTRUCTURING IN INDIA
}

\author{
Shrutilekha Barman \\ $\mathrm{PhD}$ Research Scholar, Department of Political Science, North-Eastern Hill University \\ Shillong, Meghalaya.
}

\begin{abstract}
Among the issues concerning environment, global warming is drawing the highest attention in the global political landscape. The increased volumes of greenhouse gases such as carbon dioxide $\left(\mathrm{CO}_{2}\right)$, methane $\left(\mathrm{CH}_{4}\right)$, nitrous oxide $\left(\mathrm{N}_{2} \mathrm{O}\right)$, and ozone $\left(\mathrm{O}_{3}\right)$, water vapor $\left(\mathrm{H}_{2} \mathrm{O}\right)$ in the atmosphere is positively correlated with global temperature. The main political concern about global warming began during the end of 1980s when US broke out the worst high-temperature. The extensive natural disasters drew public attention to the habitat and the issue of global warming was extensively covered by media, transforming the issue from science to politics. India as a responsible country with high moral ground is always devoted to emission reduction which allows the country to gain widespread respect and admiration throughout the world despite being a developing country.
\end{abstract}

Keywords: Global Warming, Climate Change, Environment, greenhouse gases, politicization, high temperature.

Cite this article: Shrutilekha Barman, Politicization of Global Warming and Energy

Restructuring in India, international journal of management 11(12), 2020, pp. 1044-1048.

http://iaeme.com/Home/issue/IJM?Volume=11\&Issue=12

\section{INTRODUCTION}

Climate change is the most important issue in the global political landscape. Global warming is the term used to describe a gradual increase in the average temperature of the Earth's atmosphere and its oceans, a change that is believed to be permanently changing the Earth's climate. Over the last 10,000 years Earth has experienced a very stable climate and life has adapted to it. Recently, however, the Earth has seen an increase in temperature change and many scientists now believe that there is a direct link between this warming and emissions of greenhouse gases such as carbon dioxide (CO2) and nitrogen oxides (NOx) caused by human activities[1]. Since the beginning of the Industrial Revolution (around 1750) atmospheric concentration of carbon dioxide have increased by $45 \%$, from $280 \mathrm{ppm}$ to $415 \mathrm{ppm}$ in 2019[2]. The greater part of anthropogenic carbon dioxide emissions come 
from combustion of fossil fuels, specifically coal, oil, and natural gas, with additional contributions coming from deforestation, changes in land use, soil erosion and agriculture (including livestock)[3]. Since global warming is an issue related to the risk of human health, all kinds of power starting from scientific to political started taking part in study on global warming and gradually won great popular support as both media and governments repeatedly propagated and stressed on the issue of climate change.

\section{METHODOLOGY}

The study is analytical and descriptive based on secondary sources of data. The secondary data is collected from various sources like journals, reports, articles and newspapers.

\section{GLOBAL WARMING: JOURNEY FROM SCIENCE TO POLITICAL SCIENCE}

In 1896, Svante Arrhenius, a Swedish chemist, used basic principles of physical chemistry for the first time to put forward the calculation report of "carbon dioxide (CO2) leading to global warming" and pointed out that with increasing content of carbon dioxide in atmosphere, Earth's average temperature will increase [4]. But the other scientists of that time believed climate would be self-regulating [5]. However in 1938 Guy Stewart Callendar, a Canadian steam engineer by profession published evidence that climate was warming due to the increasing level of $\mathrm{CO}_{2}$ in atmosphere,[6] but his calculations met the same objections. Later in 1960 an American Chemist David Keeling, by performing a large number of measurements revealed that "human-caused carbon dioxide emissions are large enough to cause global warming" [7][8]. Gradually the issue of "global warming" became sensational topic for the scientists. During 1970-1980s, many scientists published their key findings regarding global warming in different books and journals. Since global warming is an issue related to the risk of human health, all kinds of power starting from scientific to political started taking part in study on global warming and how to restrict it in order to hold out against further deterioration of environment.

In 1988, Intergovernmental Panel on Climate Change (IPCC) was founded by United Nations body for assessing the science related to climate change [9]. IPCC covers scientific, technical and socio-economic information relevant to understanding the scientific basis of risk

of human-induced climate change, its potential impacts and options for adaptation and mitigation, keeping close relationship with the national laboratories, weather bureaus, and scientific institutions in different countries [10]. IPCC searches the papers related to climate change released in the leading publications and publishes the climate assessment report every five year which provides the political chiefs of every country to take decisions regarding global warming. Thus, IPCC acts as a bridge between a scientific body and an intergovernmental political organisation.

In 1992 United Nations Framework Convention on Climate Change (UNFCCC) was formed to "prevent dangerous anthropogenic interference with the climate system", but global emissions have risen since then. In 1997 Kyoto Protocol was adopted in Kyoto of Japan which extends UNFCC by committing industrialized countries to limit and reduce greenhouse gases (GHGs) emissions in accordance with agreed individual targets [11]. In 2011 then President George W. Bush of the United States withdrew from Kyoto Protocol on the basis that it exempts almost $80 \%$ of the world including most populous countries like China and India and would cause serious harm to the US economy.

In 2015 all UN countries negotiated the Paris Agreement with the aim of strengthening the global response to the threat of climate change by keeping climate change well below $2{ }^{\circ} \mathrm{C}$, from the pre-industrial era, before the end of the century. The agreement replaced the Kyoto 
Protocol. There is no binding emission target set in this agreement. Instead, procedure of revaluating the collective progress towards achieving the purpose of the Agreement every five years and to inform further individual actions by Parties has been made binding [12].

\section{ADJUSTMENT OF INDIA'S ENERGY MODE}

As third largest country concerning carbon dioxide emission in the world, India bears heavier international responsibilities in terms of emission reduction. Nevertheless, India always keeps positive attitude and has been consistently taking new clean energy structure targeted at reduction of carbon emission. To ensure sustainable development and energy security India is trying to cut its dependency on conventional energy by covering all major renewable energy sources such as, biogas, biomass, solar energy, wind energy, small hydro power and the other emerging technologies.

In 2015 India submitted the first round of national climate action plan with some targets that will have to be achieved by 2030 under the Paris Agreement. Three major goals has been set which are to be achieved for the period between 2020 and $2030-$

- Increase the share of non-fossil fuels to $40 \%$ of the total electricity generation capacity

- To reduce the emission intensity of the economy by 33 to $35 \%$ by 2030 from 2005 level, and

- To create additional carbon sink of 2.5 -3 billion tonnes of $\mathrm{CO}_{2}$ equivalent through additional forest and tree cover [13].

\section{RESULT AND DISCUSSION}

Table 1 shows the ranking of countries that emitted the most carbon dioxide in 2016 where India lies in $3^{\text {rd }}$ rank. But as India is the second largest populous country in the world after China it becomes important to observe the per capita emissions of the country. India ranks $20^{\text {th }}$ when per capita emission of the countries is considered.

Table 1. Top 10 countries that emitted the most carbon dioxide in 2016

\begin{tabular}{|c|c|c|}
\hline Rank & Country & $\mathbf{C O}_{2}$ emission (total) \\
\hline 1 & China & $9056.8 \mathrm{MT}$ \\
\hline 2 & United States & $4833.1 \mathrm{MT}$ \\
\hline 3 & India & $2076.8 \mathrm{MT}$ \\
\hline
\end{tabular}

MT $=$ Metric megatons. $\mathrm{T}=$ Metric tons

Source: https://www.ucsusa.org/resources/each-countrys-share-co2-emissions[14]

\subsection{Nuclear Energy}

Presently, in India, nuclear power ranks fifth as a source of electricity generation after coal, gas, hydroelectricity, wind power, etc. Since India has never signed Nuclear Non-Proliferation Treaty due to which India was excluded from trade in nuclear plant and materials for 34 years and ultimately it hampered its development of civil nuclear energy. India has no significant uranium-235 reserves and the country is dependent on uranium imports to fuel its nuclear power industry. The Indian government had set a target of $63 \mathrm{GW}$ of nuclear power capacity by 2031-32 which later in 2018, the government stated that would fall short and that the total nuclear capacity is likely to be about $22.5 \mathrm{GW}$ by the year 2031[15]. The Government of India further focuses on an ambitious nuclear energy program with an aim to meet $25 \%$ of the total energy demand through nuclear energy by $2050[16]$. 


\subsection{Renewable Energy Sources}

In 2019, India was ranked as the fourth most attractive renewable energy market in the world [17]. As per the 31.12.2018, the installed capacity of total renewable power (excluding large hydropower) in the country amounted to $74.08166 \mathrm{GW}$. This amount will be higher in coming years as till 2019 only small hydro power less than $25 \mathrm{MW}$ in capacity were categorised as renewable, which cabinet amended and gave renewable status to Large Hydro Power[18].

Table 2: The installed capacity of renewable energy in India - source-wise (MW)

\begin{tabular}{|l|l|l|l|l|l|l|}
\hline Financial year & $\begin{array}{l}\text { Small hydro } \\
\text { power (MW) }\end{array}$ & Wind (MW) & $\begin{array}{l}\text { Biomass } \\
\text { cogeneration } \\
\text { (MW) }\end{array}$ & $\begin{array}{l}\text { Waste-to- } \\
\text { energy } \\
\text { (MW) }\end{array}$ & Solar (MW) & $\begin{array}{l}\text { Total } \\
\text { renewable } \\
\text { capacity } \\
\text { (MW) }\end{array}$ \\
\hline As of 31.12.2018 & 4517.45 & $35,138.15$ & 9075.50 & 138.30 & 25212.26 & $74,081.66$ \\
\hline $2017-2018$ & 4485.81 & $34,046.00$ & 8700.80 & 138.30 & 21651.48 & $69,022.39$ \\
\hline $2016-2017$ & 4379.86 & $32,279.77$ & 8181.70 & 114.08 & 12288.83 & $57,244.23$ \\
\hline $2015-2016$ & 4273.47 & $26,777.4$ & 4831.33 & 90.58 & 6762.85 & $45,924.04$ \\
\hline $2014-2015$ & 4055.36 & $23,354.35$ & 4418.55 & 90.58 & 3743.97 & $38,959.16$ \\
\hline $2013-2014$ & 3803.68 & $21,042.58$ & 4013.55 & 90.58 & 2631.93 & $34,988.00$ \\
\hline $2012-2013$ & 3643.17 & $18,484.99$ & 3601.03 & 126.08 & 1686.44 & $27,541.71$ \\
\hline $2011-2012$ & 3410.52 & $16,896.6$ & 3135.33 & 119.68 & 941.31 & $24,503.44$ \\
\hline $2010-2011$ & 2913 & $12,806.54$ & 2600.13 & 102.46 & 32.39 & $18,454.52$ \\
\hline $2009-2010$ & 2604.92 & $10,647.45$ & 2167.73 & 95.01 & 6 & $15,521.11$ \\
\hline $2007-2009$ & 2160.48 & 9344.13 & 1650.43 & 85.25 & 2.12 & $13,242.41$ \\
\hline & 2045.07 & 7666.84 & 1325.63 & 85.75 & 2.12 & $11,125.41$ \\
\hline
\end{tabular}

Source:http://www.cea.nic.in/reports/monthly/executivesummary/2018/exe_summary-12.pdf[19]

Table 2 shows the installed capacity of renewable energy over the last 10 years until 31.12.2018. During this period wind energy contributed highest accounting for over $47 \%$ of cumulative installed renewable capacity, followed by solar power - 34\%, biomass cogeneration $-12 \%$, and small hydropower $-6 \%$.

\section{CONCLUSION}

Transformation of Global warming issue from science to political science makes every country responsible to reduce carbon dioxide emission and substitute conventional fossil fuels with clean energy. India as a responsible country with high moral ground is always devoted to emission reduction and sets world's largest expansion plan in renewable energy by 2022 . With this in coming few years India will gain widespread respect and admiration throughout the world.

\section{REFERENCE}

[1] Anjali Goel1 and Ranjana Bhatt (2012), "Causes and Consequences of Global Warming". International Journal of Life Sciences Biotechnology and Pharma Changes, Vol.1 (1), 27-31.

[2] https://techcrunch.com/2019/05/12/co2-in-the-atmosphere-just-exceeded-415-parts-permillion-for-the-first-time-in-human-history/. Accessed on $12^{\text {th }}$ March, 2020.

[3] https://www.epa.gov/ghgemissions/global-greenhouse-gas-emissions-data. Accessed on $12^{\text {th }}$ February, 2020. 


\section{Shrutilekha Barman}

[4] Svante, A.(1896) "On the Influence of Carbonic Acid in the Air upon the Temperature of the Ground". The London, Edinburgh, and Dublin Philosophical Magazine and Journal of Science (fifth series), Vol. 41(251), 237-275.

[5] Weart, S. R. (2008). The Discovery of Global Warming, Harvard University Press.

[6] Callendar, G. S. (1938). "The artificial production of carbon dioxide and its influence on temperature". Quarterly Journal of the Royal Meteorological Society. Vol. 64(275), 223-240.

[7] Keeling, Charles D. (1998). "Rewards and Penalties of Monitoring the Earth". Annual Review of Energy and the Environment. Vol. 23, 25-82.

[8] Keeling, CD (1997). "Climate change and carbon dioxide: An introduction". Proceedings of the National Academy of Sciences of the United States of America. Vol.94 (16), 8273-8274.

[9] https://www.ipcc.ch/. Accessed on $21^{\text {st }}$ February, 2020.

[10] IPCC. "Principles Governing IPCC Work" (PDF). Accessed on 21 $1^{\text {st }}$ February, 2020.

[11] https://unfccc.int/kyoto_protocol. Accessed on $22^{\text {nd }}$ February, 2020.

[12] https://climatefocus.com/sites/default/files/20151228\%20COP\%2021\%20briefing\%20FIN.pdf . Accessed on $12^{\text {th }}$ January, 2020.

[13] "India's carbon dioxide emission up 5\%". The Hindu, March 26, 2019.

[14] https://www.ucsusa.org/resources/each-countrys-share-co2-emissions. Accessed on $3^{\text {rd }}$ March, 2020 .

[15] https://world-nuclear.org/information-library/country-profiles/countries-g-n/india.aspx. Accessed on $23^{\text {rd }}$ March, 2020.

[16] http://indianuclearenergy.com/. Accessed on $3^{\text {rd }}$ April, 2020.

[17] https://www.investindia.gov.in/sector/renewable-energy. Accessed on $3^{\text {rd }}$ March, 2020.

[18] "Large hydro projects get 'renewable energy' status". The Hindu, March 7, 2019.

[19] Central Electricity authority of India (2018), Government of India. Available at http://www.cea.nic.in/reports/monthly/executivesummary/2018/exe_summary-2.pdf.Accessed $31^{\text {st }}$ January, 2020. 